\title{
Lung epithelial stem cells and their niches: Fgf10 takes center stage
}

\author{
Thomas Volckaert ${ }^{1,2,3}$ and Stijn De Langhe ${ }^{1,4^{*}}$
}

\begin{abstract}
Throughout life adult animals crucially depend on stem cell populations to maintain and repair their tissues to ensure life-long organ function. Stem cells are characterized by their capacity to extensively self-renew and give rise to one or more differentiated cell types. These powerful stem cell properties are key to meet the changing demand for tissue replacement during normal lung homeostasis and regeneration after lung injury. Great strides have been made over the last few years to identify and characterize lung epithelial stem cells as well as their lineage relationships. Unfortunately, knowledge on what regulates the behavior and fate specification of lung epithelial stem cells is still limited, but involves communication with their microenvironment or niche, a local tissue environment that hosts and influences the behaviors or characteristics of stem cells and that comprises other cell types and extracellular matrix. As such, an intimate and dynamic epithelial-mesenchymal cross-talk, which is also essential during lung development, is required for normal homeostasis and to mount an appropriate regenerative response after lung injury. Fibroblast growth factor 10 (Fgf10) signaling in particular seems to be a well-conserved signaling pathway governing epithelial-mesenchymal interactions during lung development as well as between different adult lung epithelial stem cells and their niches. On the other hand, disruption of these reciprocal interactions leads to a dysfunctional epithelial stem cell-niche unit, which may culminate in chronic lung diseases such as chronic obstructive pulmonary disease (COPD), chronic asthma and idiopathic pulmonary fibrosis (IPF).
\end{abstract}

\section{Review}

Region-specific stem cells maintain and repair the adult lung epithelium

The adult lung epithelium is replaced over time, albeit very infrequently in comparison to organs exhibiting constant cellular turnover such as the skin and intestine. However, after injury, the lung harbors a remarkable capacity to regenerate and restore its function. This is dramatically illustrated after unilateral pneumectomy, which induces an expansion of stem cell populations and compensatory growth of the remaining lung to reestablish respiratory capacity [1]. The composition of the lung epithelium varies along a proximal-distal axis (Figure 1A), which is reflected in the diverse physiological functions of the lung. In the mouse, the pseudostratified epithelium of the trachea and main stem bronchi consists

\footnotetext{
* Correspondence: delanghes@njhealth.org

'Department of Pediatrics, Division of Cell Biology, National Jewish Health, 1400 Jackson St, Denver, CO 80206, USA

${ }^{4}$ Department of Cellular and Developmental Biology, School of Medicine, University of Colorado Denver, 12605 E 16th Avenue, Aurora CO 80045, USA Full list of author information is available at the end of the article
}

of ciliated cells, club (also known as Clara) cells, a few mucus/goblet cells, and relatively undifferentiated basal cells, which express the transcription factor transformation-related protein 63 (Trp63 or p63), cytokeratin (Krt) 5 and/or Krt14. In the smaller intralobar bronchioles, the pseudostratified epithelium now transitions into a simple single columnar to cuboidal epithelial layer devoid of basal cells and containing mostly club and ciliated cells interspersed with single or clustered neuroendocrine (NE) cells termed NE bodies (NEBs), which are most frequently located at airway bifurcations. Of note, the basal cellcontaining pseudostratified epithelium in human lungs extends to the distal bronchioles [2]. In the most distal regions of the lung, approximately $90 \%$ of the alveolar epithelium is composed of flattened alveolar type (AT) I cells, which are in close apposition to the capillary endothelium, allowing for rapid and efficient gas exchange, and cuboidal ATII cells that express surfactant. It is now becoming clear that these different epithelial regions in the lung are maintained and repaired by distinct stem cell populations.

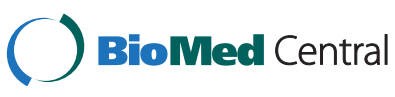




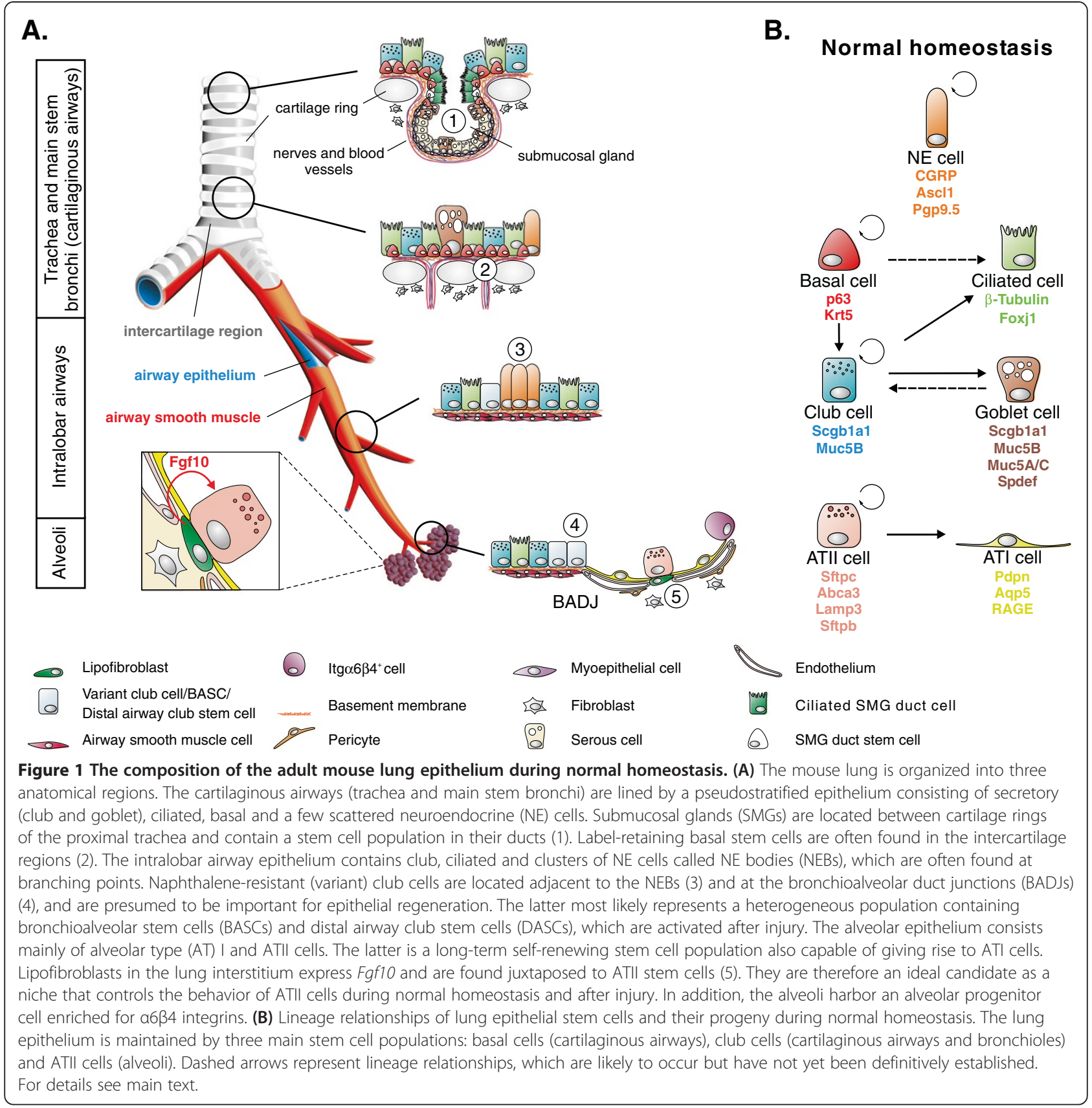

\section{Maintaining lung epithelium during normal homeostasis} Lineage tracing experiments during normal homeostasis have identified three main stem cell populations responsible for maintaining the lung epithelium: basal cells, club cells and ATII cells. Their lineage relationships are depicted in Figure 1B. Basal cells in the proximal airways are a bona fide stem cell population that gives rise to club and ciliated cells [3-6]. Club cells are also able to selfrenew and give rise to ciliated cells and therefore meet the stem cell criteria as well. They are the predominant cell population responsible for maintaining the bronchiolar epithelium. In the trachea however, their contribution to epithelial self-renewal seems to be minimal, and as a population, they are replaced over time by new club cells derived from basal cells [3,7]. NE cells self-renew but under normal homeostatic conditions do not give rise to other epithelial cell lineages [8]. The alveolar epithelium is maintained by ATII stem cells, which can self-renew and can give rise to ATI cells $[9,10]$.

\section{Stem cell populations contributing to epithelial regeneration after lung injury}

The lung is directly exposed to the outside environment and must therefore be able to respond quickly and effectively to 
inhaled particles, pathogens and harmful gases. The conducting airway epithelium is therefore designed to be a crucial primary defense mechanism by mediating mucociliary clearance and forming a protective physical barrier, which maintains its structural integrity and is vital for normal lung function. By exposing mouse lungs to different types of injury it is thought that different stem cell populations are engaged, depending on the location and extent of injury. In the trachea, $\mathrm{SO}_{2}$ or naphthalene injury kills most luminal cell types leaving behind a few surviving club cells and an intact basal cell layer (Figure 2A). Surviving club cells proliferate and contribute to epithelial restoration, but basal cells are the most important cell type mediating tracheal regeneration under these conditions [3,7]. A Krt14 ${ }^{+}$basal cell-like stem cell population located in submucosal gland (SMG) ducts has been shown to drive epithelial regeneration after severe epithelial injury using a tracheal transplant model of hypoxic ischemia, which

A.
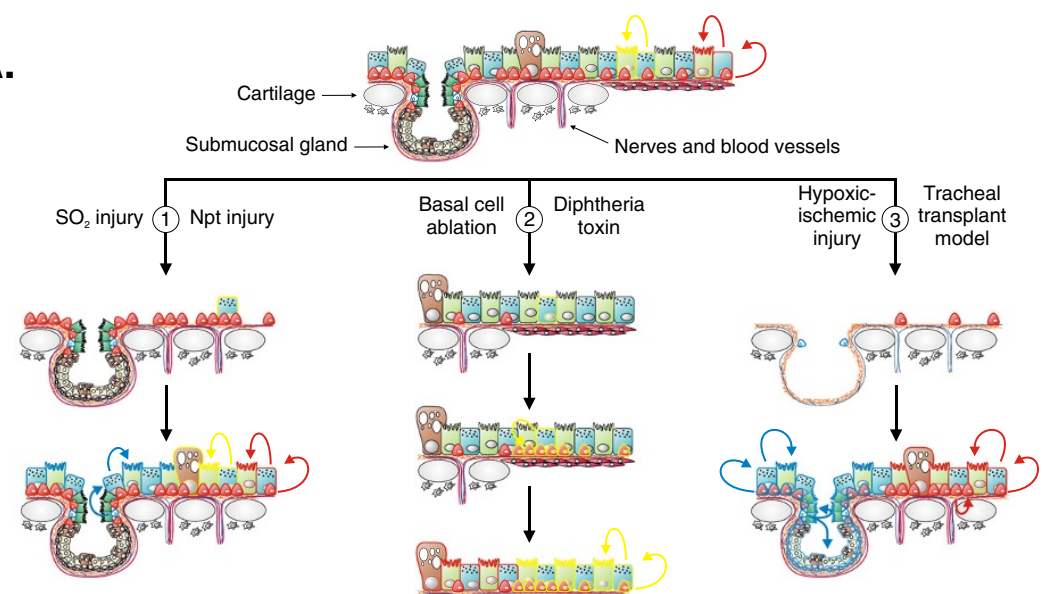

B.

A. After $\mathrm{SO}_{2} / \mathrm{Npt}$ injury

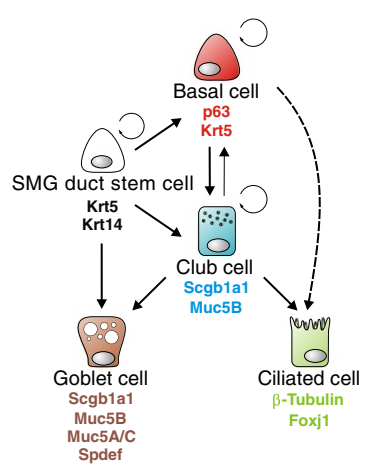

After diphtheria toxinmediated basal cell ablation

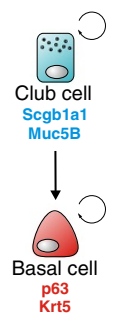

After hypoxic ischemic injury/ Tracheal transplant model

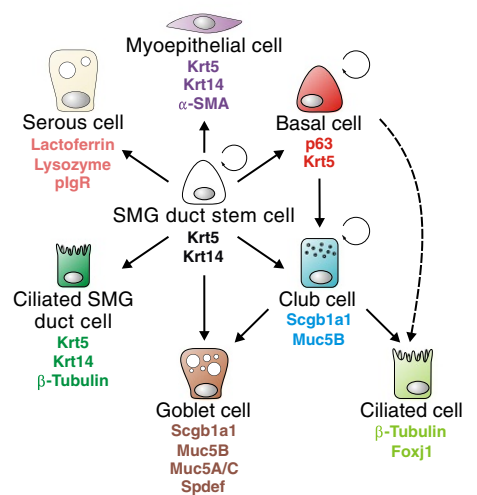

Figure 2 Stem cell populations contributing to regeneration of the proximal airway epithelium. (A) Widely used tracheal injury models such as the $\mathrm{SO}_{2}$, the naphthalene (Npt), and the tracheal transplant models, are used to study the contribution of stem cell populations to epithelial regeneration. $\mathrm{SO}_{2}$ and naphthalene injury destroy most luminal cells (1). Although surviving club cells can contribute to epithelial regeneration in the trachea following injury, the majority of newly generated club and ciliated cells arise from activated basal stem cells. A basal cell-like stem cell population residing in submucosal gland (SMG) ducts can also contribute to the regenerative process under these conditions, although they are probably employed to a larger extent after more severe injury. Although basal stem cells are presumed to be at the apex of stem cell hierarchy, club cells have been shown to be able to dedifferentiate and give rise to basal cells after diphtheria toxin-mediated depletion of the basal cell population (2). Club cell-derived basal cells can then give rise to club and ciliated cells during normal homeostasis. A more drastic epithelial injury caused by the loss of blood supply is obtained by the tracheal transplant model, which destroys nearly all epithelial cells except for a few injury resistant basal cells and SMG duct stem cells (3). After blood supply is reestablished, these surviving stem cells can then restore the tracheal surface and SMG epithelium. Colored cell outlines represent lineage trace markers. (B) Lineage relationships of lung epithelial stem cells and their differentiated progeny during regeneration of the tracheal epithelium after $\mathrm{SO}_{2}$ /naphthalene injury (left), diphtheria toxin-mediated basal cell depletion (middle) and hypoxic ischemic injury using the tracheal transplant model (right). Dashed arrows represent lineage relationships, which are likely to occur but have not yet been definitively established. For details see main text. 
destroys nearly all epithelial cells (Figure 2A) $[11,12]$. This stem cell population is still poorly characterized and its further study will require more advanced lineage tracing techniques. Together, these studies have led to the notion that basal stem cells can be placed at the top of stem cell hierarchy in the trachea, a concept which has recently been complicated by the finding that diphtheria toxinmediated ablation of basal cells in the trachea results in the reprogramming of a subset of club stem cells into basal stem cells effectively restoring the basal stem cell population of the trachea [13] (Figure 2A,B). Moreover, very rare club cell-derived basal cells have also been observed after $\mathrm{SO}_{2}$-mediated tracheal injury [7]. Interestingly, p63, a master regulator required for the development of basal cells [14], induces a basal cell phenotype and squamous metaplasia when ectopically expressed in club or ATII cells [15].

A widely used model to study epithelial regeneration of the bronchioles is naphthalene injury. In the bronchioles, naphthalene selectively depletes club cells except for the few naphthalene-resistant club cells (called variant club cells in some literature) located near NEBs $[16,17]$ and at bronchioalveolar duct junctions (BADJs) [18], which then expand and re-epithelialize the damaged airways (Figure 3A). This led to the hypothesis that this subpopulation of club cells is responsible for epithelial regeneration after injury. However, after injury, the majority of surviving club cells, regardless of their location, are capable of restoring the damaged lung epithelium [7]. Interestingly, $\mathrm{NE}$ cells have been shown to demonstrate some degree of plasticity and as such are capable of not only self-renewing but also to give rise to club and club cell-derived ciliated cells after airway epithelial injury [8] (Figure 3). However, elimination of pulmonary NE cells does not impair airway epithelial regeneration after naphthalene injury [8], suggesting that the contribution of NE cells to epithelial restoration is minimal. Bronchioalveolar stem cells (BASCs) are another population of naphthalene-resistant stem cells located at the BADJ and can be identified based on their coexpression of secretory (Scgbla1) and alveolar (Sftpc) markers, [19] (Figure 1). BASCs are likely identical to the variant club stem cells located near BADJs (described above) and might also be referred to as distal airway stem cells (DASCs) [20,21]. BASCs can self-renew and give rise to both bronchiolar and alveolar cell lineages in vitro and in vivo, the latter only after catastrophic alveolar epithelial injury [19,22] (Figure 4A, B). However, lineage tracing of Scgbla1 ${ }^{+}$cells during normal homeostasis or after hyperoxia injury (which selectively destroys ATI cells) did not reveal any contribution of BASCs to alveolar regeneration [7]. Using the same Scgbla1 ${ }^{\text {CreER }}$ mice however, it was shown that $\mathrm{Scgbla1}^{+}$club cells in the distal airway can give rise to both ATI and ATII cells following catastrophic bleomycin- or H1N1-mediated injury [20,22-25] (Figure 4A,B). Thus, it seems that the deployment of BASCs depends on the severity and type of injury. Interestingly, DASCs may dedifferentiate into basal cells after catastrophic bleomycin- or H1N1-mediated injury prior to regenerating ATI and ATII cells [20,25] (Figure 4A,B). However, it remains possible that the observed increase in basal cells is due to the expansion of a minor basal cell population in the distal airways or by migration of

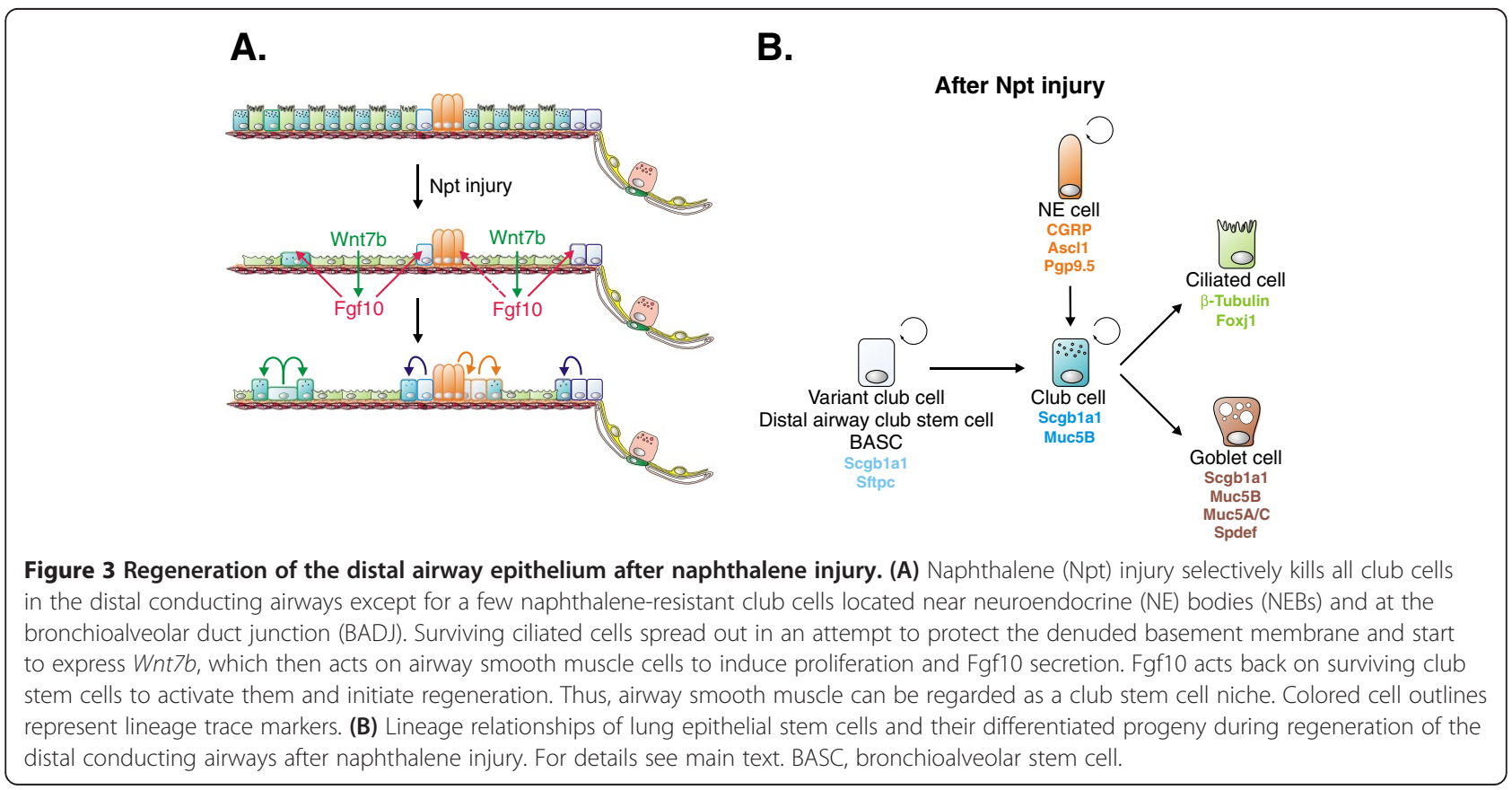




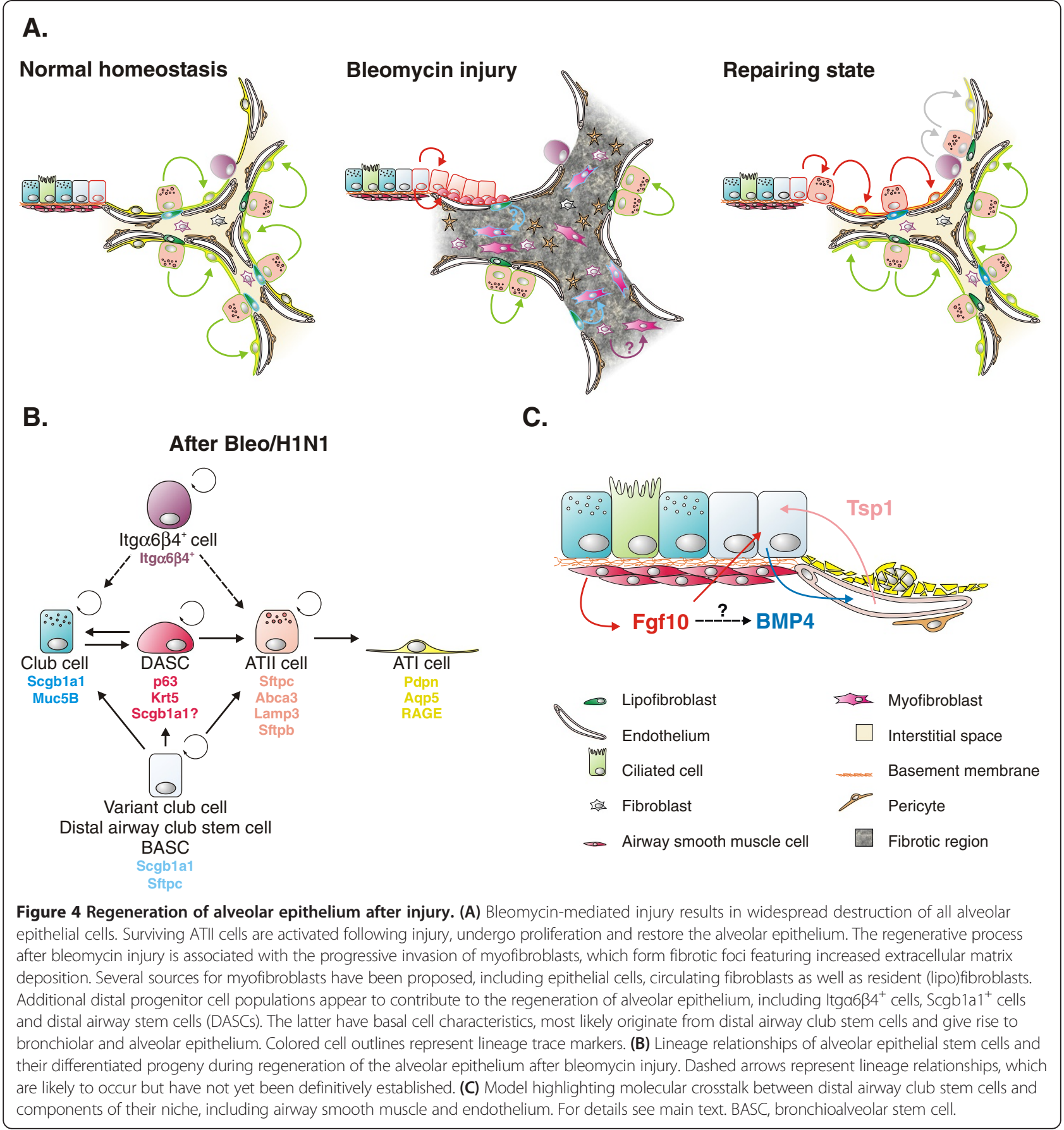

basal cells originating from the proximal airways. Future experiments combining both lineage tracing and live imaging during the repair response will help to address this. Bronchiolization is often observed as honeycomb regions in lungs from patients with idiopathic pulmonary fibrosis (IPF). These bronchiolized areas have been shown to contain basal cells [26], suggesting that in humans with IPF, regeneration of the fibrotic lung may also be mediated in part by distal airway club or basal stem cells.
Importantly, although BASCs/DASCs can contribute to alveolar regeneration, ATII cells are the main stem cell population in the lung respiratory epithelium involved in replenishing ATII cells after their diphtheria toxinmediated depletion [9], re-establishing the ATI population after hyperoxic injury $[7,10]$ and regenerating both ATI and ATII cells after bleomycin injury $[9,23]$ (Figure 4). In addition to ATII cells, an $\mathrm{Sftpc}^{-}$and integrin (Itg) $\alpha 6^{+} / \beta 4^{+}$alveolar epithelial stem cell population has recently been characterized, having the potential to give rise 
to both ATII and club cells in vitro and in vivo after injury $[27,28]$ (Figure 4B). To what extent this cell population contributes to alveolar repair after injury is not clear and will require lineage tracing to answer this question.

\section{The niche regulates epithelial stem cell behavior in the lung}

Lung stem cells must give rise to the appropriate number of differentiated progeny to achieve homeostasis and to restore the functional organ after injury. Tissue damage can dramatically change the dimensions of an organ, and after regeneration tissue growth must halt once the original organ dimensions are restored. Therefore, checks and balances are in place to prevent unwanted stem cell responses, which could lead to pathological changes compromising tissue integrity and lung function. The behavior of virtually all stem cells, whether they are pluripotent or lineage-restricted, embryonic or adult, is controlled by the interplay between intrinsic transcriptional programs and extrinsic signals [29]. The extrinsic signals are provided by the niche, a local tissue environment that hosts and influences the behaviors or characteristics of stem cells [30] and that comprises other cell types and extracellular matrix (ECM) (Figure 5). An intimate association of stem cells with their niche is critical to ensure long-term maintenance of stem cell populations, as well as to direct stem cell differentiation into the appropriate lineages. As such, the niche can maintain stem cell quiescence, promote transient activation, and keep stem cells undifferentiated [31].

\section{Fgf10 maintains the distal epithelial progenitor} population and drives basal cell differentiation in the trachea and main stem bronchi during lung development During lung development, a complex interplay between endoderm and mesoderm defines early developmental competence and cell fate. This cross-talk is orchestrated by key signals including Fgfs, Wnts, retinoic acid, Shh and Tgf $\beta$ (reviewed in [32]). Proximal-distal patterning of the lung is accompanied by the gradual restricted ability of developmental progenitors to generate the various epithelial lineages in the mature organ [33]. During early lung development, Fibroblast growth factor 10 (Fgf10), which is expressed in the distal mesenchyme and is regulated by Wnt signaling [34-36], acts on the distal lung epithelial progenitors to maintain them and prevent them from differentiating into proximal (airway) epithelial cells by inducing Sox9 and repressing Sox 2 expression [37,38] (Figure 6). Fgf10 is presented as a dimer, bound to heparin sulfate (HS) proteoglycans in the

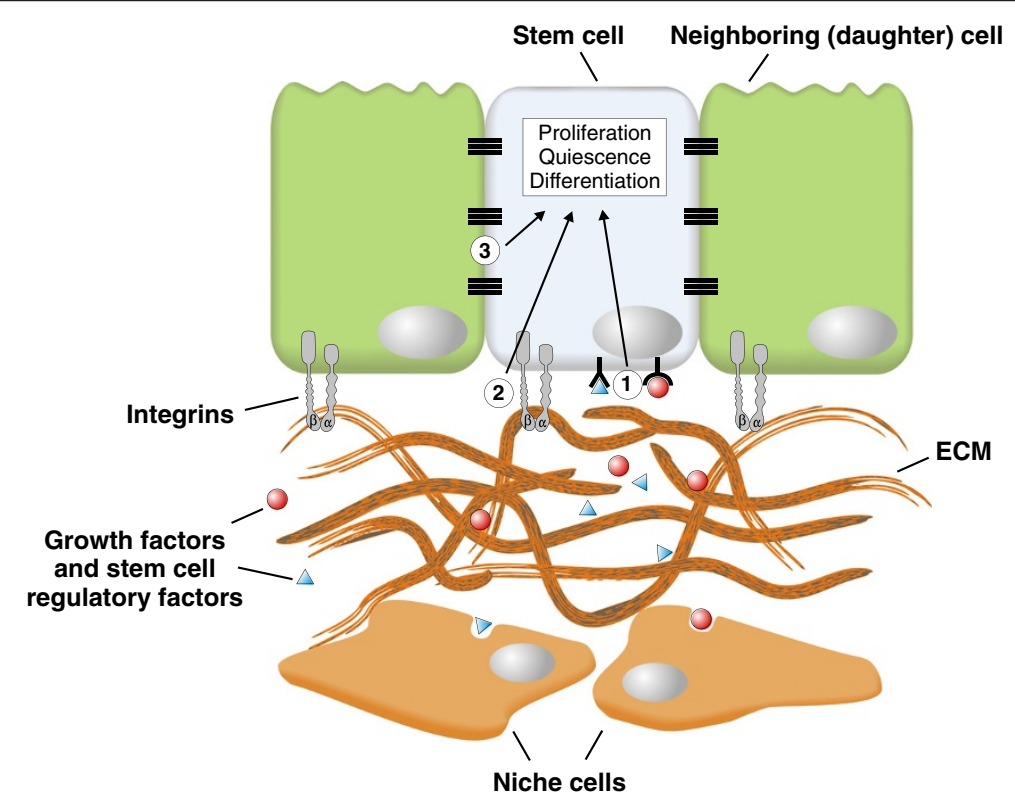

Figure 5 The epithelial stem cell niche. The behavior of epithelial stem cells is regulated by external signals, provided by the microenvironment or niche in which stem cells reside. These signals include growth factors (for example Fgf10) and other stem cell regulatory factors secreted by the niche cells, which can be a wide variety of differentiated cell types, including fibroblasts, smooth muscle cells, endothelial cells, neurons as well as neighboring stem cell progeny (1). Another important component of the stem cell niche is the extracellular matrix (ECM), which acts as a reservoir for growth factors and provides mechanical cues to stem cells, which are translated into biochemical signals through integrins via a process called mechanotransduction (2). Finally, direct cell-cell contact between stem cells and their neighboring progeny, which is mediated by adherens and tight junctions, can also provide essential feedback information to their parent stem cells (3). Integration of these different types of niche signals regulates stem cell activity and behavior such as enhancing stem cell quiescence, promoting transient proliferation or differentiation, and maintaining stem cells in an undifferentiated state. 


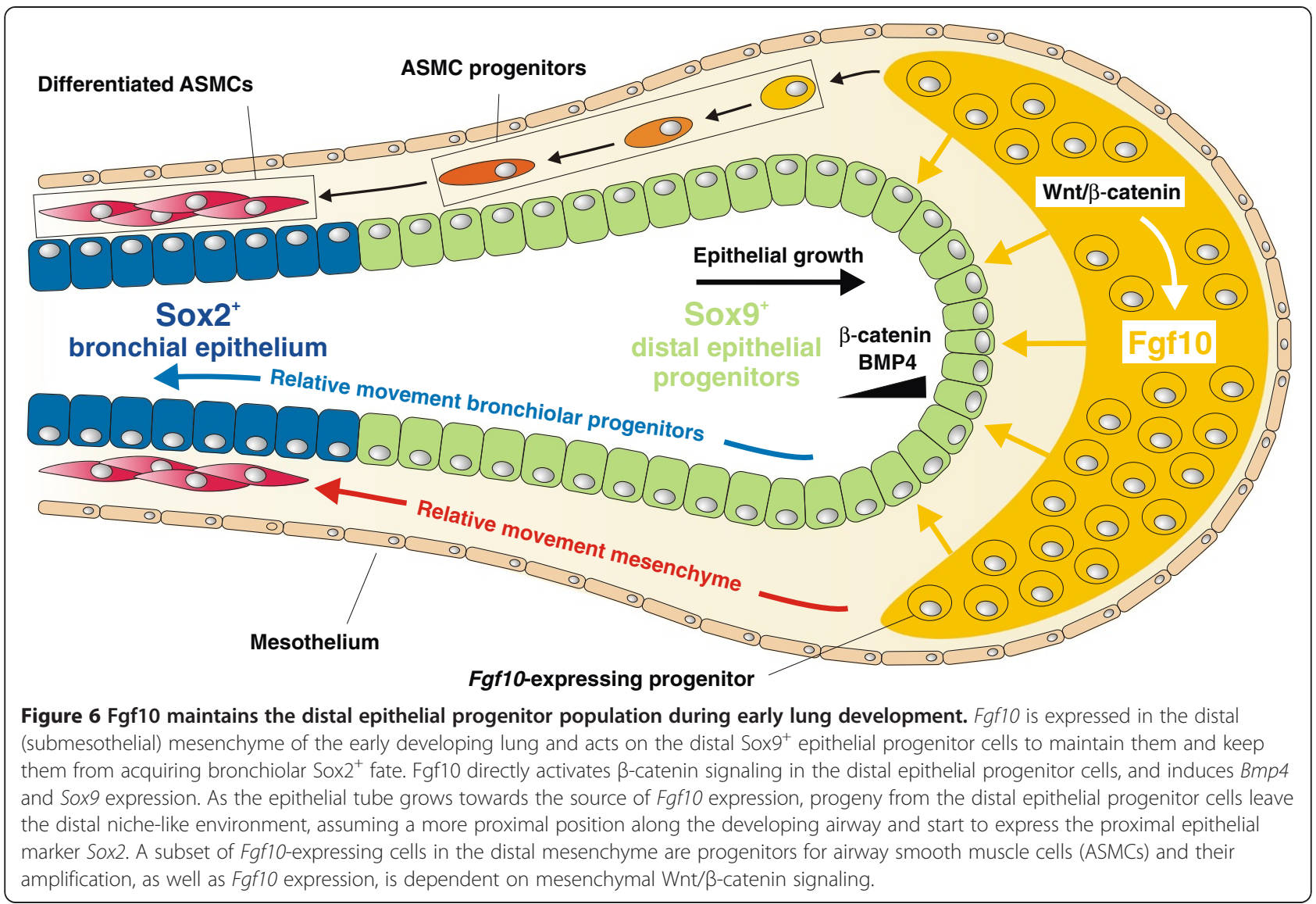

basement membrane (BM), to its receptor Fgfr2b on distal epithelial progenitor cells [39-42]. However, as the lung epithelium grows out, more proximally located cells become further displaced from this distal source of Fgf10 and gradually start to differentiate $[33,37,38,42,43]$. Precisely regulated Fgf1O expression and presentation via HS proteoglycans is necessary during early development so that high levels are achieved distally to promote rapid expansion of embryonic progenitors. Cell surface-tethered HS chains play pivotal roles in the local retention of Fgf ligands and can spread Fgf signaling to adjacent cells within a short range [44]. Vice versa, Fgf10 suppression around the developing airway, as well as during late gestation and postnatal development, is crucial to allow for proper maturation of the lung epithelium [39-41,43-45]. In addition, ectopic Fgf10 overexpression at later stages of lung development prevents the alveolar differentiation program through the induction of Sox9 expression [43,46,47]. Interestingly, a subset of Fgf10-expressing cells in the distal mesenchyme during early lung development are progenitors for airway smooth muscle cells (ASMCs) [35,48,49] (Figure 6) and lipofibroblasts (LIFs) at later stages [50].

Fgf10 is also expressed in between tracheal cartilage rings during lung development [51-53]. In the trachea, Fgf10 signaling plays an important role in basal cell differentiation and maintenance during mouse lung development [43]. Fgf10 knockout tracheas show a 50\% reduction in basal cells compared to wild type tracheas [43]. In addition, overexpression of Fgf10 during lung development results in the ectopic differentiation of a large subset of Sox $2^{+}$airway epithelial cells into the basal cell lineage all along the conducting airway. Interestingly, inhibition of Fgf signaling from E15.5 until E18.5 resulted in a failure to maintain basal cells in the mouse trachea [43].

\section{Epithelial stem cell niches in the adult lung}

Much progress has been made in identifying the different stem cell populations involved in the maintenance and repair of the adult lung epithelium as well as their lineage relationships. However, much less is known about the nature of stem cell niches in the lung and how they influence stem cell behavior.

Cellular and molecular mechanisms important during development are often reactivated during adult injury repair and in disease. As such, we have recently identified ASMCs as a niche for club stem cells [54]. After naphthalene-mediated airway epithelial injury, surviving epithelial cells secrete Wnt7b in order to activate ASMCs by inducing their c-Myc-mediated proliferation 
and Fgf10 expression [54,55], which recapitulates a progenitor-like state (Figure 3A). Fgf10 secreted by the niche then acts reciprocally on surviving club stem cells near NEBs and at the BADJ, imparting stem cell characteristics by inducing a transient epithelial-mesenchymal transition (EMT). As a result, club stem cells break quiescence, induce proliferation and initiate epithelial repair. Short-term Fgf10 overexpression enhances airway epithelial regeneration, whereas inhibition of Fgf10 signaling reduces regenerative capacity after naphthalene injury $[54,56]$, underscoring the central role of this signaling pathway in regeneration of the bronchiolar epithelium. Interestingly, this re-expression of $F g f 10$ by ASMCs is observed after different types of airway epithelial injury, including ozone and bleomycin injury [54].

In the mouse trachea, label-retaining basal stem cells preferentially reside in SMG ducts and in intercartilage regions [57,58], two areas where Fgf10 expression is the highest [51-53,59]. Whether Fgf10 regulates SMG duct stem cells in the adult lung [11] remains to be investigated.

Interestingly, direct cell-cell contact between basal cells and club stem cells in the tracheal epithelium inhibits the reprogramming of club stem cells into basal stem cells [13]. In this context, basal stem cells themselves contribute to the club cell niche in the trachea. However, it is currently unclear what prevents club cells from reprogramming into basal cells in the lower mouse airways where basal cells are absent.

A novel subpopulation of Scgbla1 ${ }^{-}$club cells, characterized by expression of N1ICD, Scgb3a2, Uroplakin 3a (Upk3a) and SSEA-1, has been identified juxtaposed to Ascl1-expressing NEBs and remain largely uncommitted during development but can give rise to $\mathrm{Scgbla}^{+}$club and ciliated cells in the adult lung [60,61]. This cell population is lost in $\mathrm{Ascl1}^{-/-}$mice suggesting that the induction and/or maintenance of these club-like precursor cells is highly dependent on the presence of NEBs in the developing bronchi $[60,61]$. These findings together with the observation that a naphthalene-resistant subpopulation of club cells is associated with NEBs $[16,62]$ led to the hypothesis that pulmonary NEBs form a stem cell niche essential for club cell regeneration during lung injury. However, lungs lacking NE cells regenerate normally after naphthalene injury [8]. Therefore, further studies are needed to establish whether NEBs indeed provide signals to keep the adjacent naphthalene-resistant club cell population in a more progenitor-like state.

A similar cross-talk between epithelial stem cells and their niche is essential to maintain and regenerate the distal respiratory epithelium [63-65]. In the adult lung parenchyma, LIFs are found juxtaposed to ATII cells and are thought to contribute to the ATII stem cell niche, maintaining their stemness [9]. LIFs assist in the production of pulmonary surfactant by assimilating neutral lipids and transferring triglycerides to ATII cells for final processing of the surfactant [66-71]. In addition, LIFs also express $F g f 10$ [50,54], which has been shown to act directly on ATII cells via Fgfr2b to drive the expression of Sftpc [43,54,56,72,73]. As such, Fgf10 acts as a protective and therapeutic agent against bleomycin-induced pulmonary fibrosis [56]. Similarly, clonal expansion of the $\mathrm{Sftpc}^{-}$alveolar stem cells enriched for $\alpha 6 / \beta 4$ integrins relies on co-culture with $\mathrm{Scal}^{+}$mesenchymal cells, which can be substituted by exogenous Fgf10 [28]. An additional population of $\mathrm{CD}_{166}{ }^{-}$and $\mathrm{Fgf10} 0^{+}$adult lung mesenchymal stromal cells (MSC) exists, which functions as a progenitor for LIFs and can support lung epithelial stem cell growth in vitro due to its Fgf10 expression. As during lung development, Fgf10 expression in these cells can be inhibited by Tgfß signaling $[34,74,75]$.

Bmp4 secreted by BASCs after bleomycin injury acts on endothelial cells via Bmprla to trigger calcineurin/ NFATc1-dependent expression of thrombospondin-1 (Tsp1). This endothelial-derived Tsp1 then drives the differentiation of BASCs into the alveolar lineage via a feedback loop [22]. Interestingly, after naphthalene injury, Bmp 4 and Tsp 1 expression is downregulated, which was shown to favor the differentiation of BASCs into the club cell lineage [22]. Considering that Bmp4 is a main target gene of Fgf10 signaling [73,76-78], it is currently unclear how Fgf10 might be involved in this process since Fgf10 expression is upregulated in ASMCs and Fgf10 signaling in BASCs is activated after both naphthalene and bleomycin injury [54] (Figure 4C).

Lastly, a recent study provides insight in how the human Lgr6 $^{+}$alveolar epithelial stem cell niche is formed and maintained to effectively ensure stem cell self-renewal capacity [79]. The authors identified a paracrine circuitry in which basal levels of SDF-1 secreted by Lgr6 ${ }^{+}$stem cells recruit and prime fibroblasts to release TNF $\alpha$. This TNF $\alpha$ then leads to the activation of a TGF $\beta / \mathrm{p} 38 \alpha$-mediated autocrine loop in $\mathrm{Lgr}^{+}$stem cells, which further enhances SDF-1 production. These high SDF-1 levels then stimulate fibroblasts to produce angiogenic factors to promote angiogenesis [79].

\section{The role of cell-matrix and cell-cell adhesion in the epithelial stem cell niche}

As described above, crosstalk between stem cells and their niche crucially depends on paracrine and autocrine signaling molecules. However, the behavior of epithelial stem cells depends on the integration with several other signals as well, including direct contact with the underlying ECM as well as with neighboring epithelial cells (Figure 5).

Components of the ECM, including fibronectin, proteoglycans and collagens, anchor stem cells in their 
niche and provides them with mechanical signals, based in part on substrate rigidity $[80,81]$. This allows stem cells to respond to physical stimuli such as mechanical stress. In addition, the ECM acts as a growth factor reservoir by its ability to bind locally secreted growth factors (for example, Fgf10 and Tgf $\beta$ ) and other stem cell regulatory molecules (Figure 5), which can be released by proteases such as heparinase [82]. Integrin-mediated cell adhesion to the ECM in the niche guides stem cell fate decisions, including choices between quiescence or proliferation, self-renewal or differentiation, migration or retention, and cell death or survival [83]. For example, loss of contact with the ECM or reduced integrin expression in adherent cells triggers terminal differentiation of cultured epidermal stem cells $[84,85]$. The pulmonary ECM is subjected to a continuous turnover of more than $10 \%$ of the total ECM per day [86]. Thus a dynamic equilibrium between synthesis and degradation of the pulmonary ECM maintains a physiological balance [87]. Alterations in its composition (for example, in response to injury) lead to changes in cell shape and behavior [88], altered binding affinity or cellular distribution of cell-surface receptors [89], and different cellular responses to growth factors [90]. The BM, a specialized form of ECM separating the epithelium from the mesenchyme, is a dynamic structure produced by collaboration between stromal fibroblasts and epithelial cells. Depending on the composition and physical characteristics of the BM, different growth factors can have completely different cellular outcomes, such as cell proliferation, growth arrest, differentiation or apoptosis [91]. Moreover, tissue engineering experiments suggest that a decellularized matrix is capable of dictating exogenous stem cell fate [92], which highlights the importance of integrin-mediated stem cell-ECM communication in controlling stem cell behavior. Bidirectional signaling between epithelial stem cells and the cellular and acellular components of their niche is essential for normal tissue homeostasis, and there is clear evidence that stem cell integrins and BM proteins are involved in this communication [93].

In contrast to our increasingly extensive knowledge of pathways that regulate stem cell properties in the lung during development and regeneration, not much is known about the molecular mechanisms that keep lung stem cells largely quiescent during homeostasis or in check after a regenerative response to prevent tissue overcrowding and dysplasia. Preservation of the quiescent state by the niche is an actively regulated process that maintains the number and function of stem cells [94]. Epithelial cells form polarized cell layers that function as barriers capable of interacting with the underlying matrix as well as with neighboring epithelial cells. Epithelial cell polarity is maintained through the combined action of three major regulatory complexes: Crumbs complex, Par complex and Scribbled complex [95-97]. These complexes are important in organizing cell-cell and cellmatrix adhesion junctions, which have emerged as major signaling platforms that mediate the cross-talk between neighboring epithelial cells and the underlying ECM, thereby regulating epithelial cell differentiation and proliferation via the Hippo pathway [95,96,98-105]. For example, cultured cells arrest proliferation and cell division when the culture becomes confluent. This contact inhibition mechanism is crucial in vivo to regulate organ size and its loss is a hallmark of solid tumors $[106,107]$. An intriguing picture is emerging in which stem cell progeny are a critical niche component, providing essential feedback to their stem cell parents to control stem cell activity and behavior [30]. However, the exact mechanisms underlying (integrin-mediated) mechanotransduction by the ECM and contact inhibition in the lung remain poorly understood.

\section{Epithelial stem cells and their niches in chronic lung diseases}

Chronic lung disorders, such as IPF, asthma and chronic obstructive pulmonary disease (COPD), are characterized by the progressive remodeling of the airways and/or parenchyma, which irreversibly leads to lung dysfunction. In most cases their etiology is not well understood and current therapeutics are aimed at ameliorating rather than curing these diseases. Tissue architecture remodeling involves pathological changes in the composition and physiological function of the epithelium. During normal homeostasis as well as after injury, lung epithelial stem cells need to give rise to the right amount of differentiated progeny while maintaining their selfrenewing ability depending on the physiological context. Disrupting this balance can lead to excessive differentiation and stem cell exhaustion, hypoplasia or squamous metaplasia. Such abnormal changes in stem cell function may result from inherent (epi)genetic changes or a dysfunctional stem cell niche. Furthermore, pathological changes to the lung epithelium may drastically influence the crosstalk between stem cells and their niche, which further contributes to disease progression by inducing abnormal changes in mesenchymal components, such as ASMC hyperplasia and fibroblast activation leading to excessive ECM deposition and fibrotic scarring. Chronic injury and prolonged activation of repair pathways are thought to result in decreased repair potential by exhausting the stem cell pool, which leads to defective repair and progressive airway remodeling by promoting a fibrotic response [63]. 


\section{Asthma}

Pathological hallmarks in asthma are an increase in smooth muscle mass surrounding the airway wall, SMG hyperplasia and thickening of the basal lamina beneath the seemingly 'normal' BM [108]. The latter is accompanied by an increase in the number and activity of subepithelial myofibroblasts with their capacity to lay down new matrix $[109,110]$. There is also overwhelming evidence for basal cell hyperplasia [111,112] and goblet cell metaplasia (GCM) [113] in the asthmatic conducting airways. In asthmatic patients, goblet cells spread down to the more peripheral airways, where they normally do not exist $[114,115]$. GCM is not due to the proliferation of pre-existing goblet cells but rather to the transdifferentiation of club cells to goblet cells [116-118]. In fact, goblet cells can actually be regarded as club cells secreting a lot of mucins [119-122].

New paradigms in asthma research point to a central role for the epithelium and chronic activation of epithelial repair pathways as a major cause of airway remodeling and the development of persistent alterations in airway function [123]. This is a shift away from the traditional view in which T-helper 2 (Th2)-type inflammation is considered to be a primary cause in asthma pathogenesis. At its onset, asthma is associated with structural changes in the airways often in the relative absence of airway inflammation [124-126]. A new paradigm for persistent asthma is emerging of a damaged epithelium that repairs incompletely and leads to a chronic wound scenario with the secretion of a range of growth factors capable of driving structural changes linked to airway remodeling [127-129]. Thus, asthma may primarily be an epithelial disorder and its etiology as well as its clinical manifestations could likely be caused by altered epithelial physical and functional barrier properties rather than being purely linked to allergic pathways. In support of this, naphthalene-mediated airway epithelial injury has recently been shown to cause airway hyper-responsiveness [130]. A direct link between a compromised barrier function and allergy has been supported by recent findings in atopic dermatitis. Mutations in the epidermal barrier protein filaggrin (encoded by the Flg gene) lead to a defect in epithelial barrier function resulting in increased epithelial permeability and penetration of exogenous substances [131,132]. Disruption of the columnar epithelium by breaking tight junctions or not reforming them efficiently enables tissue damaging agents and infectious particles to penetrate the airway wall, which facilitates toxic, immune, and inflammatory responses accompanying tissue damage [133-135]. There is also a link between a compromised epithelial barrier function and the induction of GCM. Epidermal growth factor (EGF), a key epithelial cell-derived factor that promotes GCM, is normally secreted on the basolateral side of the epithelium and sequestered from its receptor on the apical side through intact adherens and tight junction barriers between neighboring epithelial cells [123,136,137]. The recent conceptual change in asthma pathogenesis raises the interesting possibility that disordered epithelial signaling pathways not only drive susceptibility to environmental insults but also the inflammation and remodeling responses that follow. Similarities between organ morphogenesis and wound healing responses have led to a new concept in which chronic airway inflammation is supported by the structural components of remodeling through activation of the epithelial stem cell-niche unit [138].

Interestingly, the Wnt pathway is induced in ASMCs in a mouse model for asthma [139], whereas epithelial Fgf10, as well as downstream Notch signaling, has been shown to be implicated in mucous/goblet cell hyperplasia [37,119]. In addition, both Fgf10 and downstream Notch signaling are involved in maintaining club stem cells to prevent them from differentiating into terminally differentiated ciliated cells $[43,119,140]$. These findings suggest that under conditions of chronic injury, the lung may invoke the same signaling pathways which are activated in response to acute injury [54]. Unlike human lungs, mouse lungs only have very few goblet cells in the upper airways. Fgf10 secreted by ASMCs, possibly by activating the Notch pathway, can induce club cell to goblet cell transdifferentiation in the repairing upper airway after naphthalene injury in the mouse [54]. Thus, chronic activation of Wnt-Fgf10 epithelial-mesenchymal crosstalk is likely involved in ASMC proliferation and airway remodeling observed in asthma patients. The sustained stimulation of these pathways may eventually lead to epithelial stem cell depletion and fibrosis. In this regard, it is interesting to note that Snail1 expression is induced downstream of Fgf10 or Notch signaling in club stem cells during airway epithelial regeneration resulting in a transient EMT [54]. Interestingly, use of a mouse model of acute liver fibrosis on a hepatocyte-specific Snail1 knockout showed that Snail1 plays a crucial role in the progression of liver fibrosis without driving a full EMT. Instead, Snail1 was shown to drive the expression of growth factors, ECM components and proinflammatory mediators [141].

\section{Idiopathic pulmonary fibrosis}

IPF is a devastating, age-related lung disease with an unknown etiology that is refractory to treatment and has a poor survival rate. Widespread damage to the epithelium and/or exhaustion of the epithelial stem cell pool, such as in IPF patients with certain telomerase mutations [142-149], ultimately leads to epithelial loss. This results in a denuded basal lamina, serum protein exudation and remodeling of the underlying ECM, mediated by fibrotic 
scarring $[63,64,150]$. Similar to asthma, IPF was once thought to be driven by chronic inflammation. However, the efficacy of anti-inflammatory or immunosuppressive drugs is inadequate, which urged reassessing the role of inflammation in IPF. Indeed, current evidence indicates that the fibrotic response may primarily be caused by abnormally activated alveolar epithelial (stem) cells [64]. A main hallmark of IPF is an increase in hyperplastic and hypertrophic ATII epithelial stem cells despite widespread epithelial damage and apoptosis. These cells express mediators such as Tgf $\beta$, which induce the formation of myofibroblast foci through the proliferation and transdifferentiation of resident mesenchymal (niche) cells and the attraction of circulating fibrocytes [23,64]. The myofibroblastic foci secrete excessive amounts of ECM, mainly collagens and fibronectin (FN), resulting in fibrotic scarring and progressive remodeling of tissue architecture reminiscent of abnormal repair. Disruption of the tissue-specific epithelial stem cell niche by the fibrotic ECM may further result in aberrant stem cell activation and/or stem cell loss. This prevents proper regeneration and leads to permanent and irreversible tissue scarring, which compromises normal lung function. Abnormal redeployment of developmental epithelialmesenchymal interactions between epithelial stem cells and their niches have been suggested to play a role in the pathogenic mechanisms that connect IPF with aging and aberrant ATII cell activation [63-65]. After epithelial injury, lung epithelial stem cells and their niches will attempt to restore the damaged epithelium. However, if effective re-epithelialization fails then a process of destructive remodeling and aberrant cellular differentiation is initiated, which produces a dysfunctional disease state shared by several parenchymal pulmonary disorders [63]. IPF patients show a significant loss of ATI cells $[64,65]$. Moreover, the differentiation of ATII into ATI cells is perturbed in IPF due to aberrant ECM remodeling and changes to the BM structure [64,65]. At this point it is unclear whether there is a correlation between the reduction in ATI cells and a fibrotic response in IPF. However, ATI cells express some important antifibrotic factors such as caveolin-1, which is involved in FN turnover [151,152], and mice lacking caveolin-1 or -2 develop spontaneous lung fibrosis [64,151-153].

\section{Chronic obstructive pulmonary disease}

COPD is another chronic lung disorder that develops mainly in smokers and clinically manifests itself through chronic bronchitis and emphysema. Epithelial remodeling includes basal cell hyperplasia and squamous metaplasia with several layers of $\mathrm{Krt}_{1} 4^{+}$basal cells, which are rare in the normal epithelium [2]. In addition, mucus hyperplasia is also frequently observed in lungs from COPD patients [2]. Interestingly, Fgf10 haploinsufficiency is linked to emphysema in COPD in humans, which further emphasizes the significance of Fgf10 expression in adult lung stem cell niches and its role in homeostasis and regeneration [154].

\section{Conclusions}

Stem cells are indispensible during normal homeostasis and regeneration to restore the form and function of an organ after injury. Great strides are being made toward identifying and characterizing stem cell populations in the adult lung. It is, however, important to keep in mind that stem cells do not act independently to perform these functions. Stem cells are subjected to tight regulatory processes so that they are activated and give rise to the right number and type of differentiated progeny at the appropriate time and place in a given biological context. In that regard, stem cells must be mobilized quickly in response to injury, but once the tissue has been restored, stem cells must also be able to revert back to their quiescent state. How exactly this information is communicated to stem cells is not well understood, but may involve dynamic feedback mechanisms between stem cells and their niche. We are now only beginning to understand the cellular and molecular constituents of the stem cell niches in the lung and how stem cell behavior is influenced by the wide variety of external signals provided by their niche. In this review, we have advocated the involvement of Fgf10, which is expressed in several stem cell niches in the lung, in stem cell maintenance and activation after injury. Developmental pathways are often recapitulated during lung repair and their chronic and sustained activation may lead to lung remodeling observed in chronic diseases such as IPF, COPD and chronic asthma. As such, determining the regulatory pathways involved in stem cell-niche interactions during adult lung homeostasis and repair after injury will pave the way for a better understanding of the molecular mechanisms underlying these devastating disorders for which there are currently few or inefficient treatments. Moreover, effectively recreating the stem cell niche in vitro in organoid cultures will be crucial for long-term expansion of lung stem cells and the development of cell replacement therapies. As such, the feasibility of colon stem cell therapy based on transplantation of colon organoids in a damaged mouse colon has recently been demonstrated [155].

\section{Abbreviations}

ASMC: airway smooth muscle cell; ATI: alveolar type I; ATII: alveolar type Il; BADJ: bronchioalveolar duct junction; BASC: bronchioalveolar stem cell; BM: basement membrane; COPD: chronic obstructive pulmonary disease; DASC: distal airway stem cell; EGF: epidermal growth factor; ECM: extracellular matrix; EMT: epithelial-mesenchymal transition; FGF10: fibroblast growth factor 10; FN: fibronectin; GCM: goblet cell metaplasia; HS: heparin sulfate; IPF: idiopathic pulmonary fibrosis; Itg: integrin; Krt: cytokeratin; LIF: lipofibroblast; NE: neuroendocrine; NEB: neuroendocrine body; SMG: submucosal gland; 
Th2: T-helper 2; Trp63 or p63: transformation-related protein 63;

Tsp1: thrombospondin-1; Upk3a: uroplakin 3a.

\section{Competing interests}

The authors declare that they have no competing interests.

\section{Authors' contributions}

TV and SDL developed the review concept, performed the literature review, created figures, wrote and revised the manuscript. Both authors read and approved the final version of the manuscript.

\section{Authors' information}

TV is a predoctoral candidate. SDL is an associate professor of pediatrics.

\section{Acknowledgements}

We apologize for those primary works that are not cited due to the scope of this review and space constraints. The authors acknowledge support from the National Institutes of Health RO1 HL092967 to SDL. The funding body did not play any role in design, collection, analysis, interpretation nor selection of data to review, writing of the manuscript or in the decision to submit the manuscript for publication.

\section{Author details}

${ }^{1}$ Department of Pediatrics, Division of Cell Biology, National Jewish Health, 1400 Jackson St, Denver, CO 80206, USA. The Inflammation Research Center, Unit of Molecular Signal Transduction in Inflammation, VIB, Technologiepark 927, 9052 Ghent, Belgium. ${ }^{3}$ Department of Biomedical Molecular Biology, Ghent University, Technologiepark 927, 9052 Ghent, Belgium. ${ }^{4}$ Department of Cellular and Developmental Biology, School of Medicine, University of Colorado Denver, 12605 E 16th Avenue, Aurora CO 80045, USA.

Received: 29 November 2013 Accepted: 4 April 2014

Published: 8 May 2014

\section{References}

1. Eisenhauer P, Earle B, Loi R, Sueblinvong V, Goodwin M, Allen GB, Lundblad L, Mazan MR, Hoffman AM, Weiss DJ: Endogenous distal airway progenitor cells, lung mechanics, and disproportionate lobar growth following long-term postpneumonectomy in mice. Stem Cells 2013, 31:1330-1339.

2. Rock JR, Randell SH, Hogan BL: Airway basal stem cells: a perspective on their roles in epithelial homeostasis and remodeling. Dis Model Mech 2010, 3:545-556.

3. Rock JR, Onaitis MW, Rawlins EL, Lu Y, Clark CP, Xue Y, Randell SH, Hogan BL: Basal cells as stem cells of the mouse trachea and human airway epithelium. Proc Natl Acad Sci U S A 2009, 106:12771-12775.

4. Rock JR, Gao X, Xue Y, Randell SH, Kong YY, Hogan BL: Notch-dependent differentiation of adult airway basal stem cells. Cell Stem Cell 2011, 8:639-648.

5. Hong KU, Reynolds SD, Watkins S, Fuchs E, Stripp BR: In vivo differentiation potential of tracheal basal cells: evidence for multipotent and unipotent subpopulations. Am J Physiol Lung Cell Mol Physiol 2004, 286:L643-L649.

6. Hong KU, Reynolds SD, Watkins S, Fuchs E, Stripp BR: Basal cells are a multipotent progenitor capable of renewing the bronchial epithelium. Am J Pathol 2004, 164:577-588.

7. Rawlins EL, Okubo T, Xue Y, Brass DM, Auten RL, Hasegawa H, Wang F, Hogan BL: The role of Scgb1a1+Clara cells in the long-term maintenance and repair of lung airway, but not alveolar, epithelium. Cell Stem Cell 2009, 4:525-534.

8. Song $H$, Yao E, Lin C, Gacayan R, Chen MH, Chuang PT: Functional characterization of pulmonary neuroendocrine cells in lung development, injury, and tumorigenesis. Proc Natl Acad Sci U S A 2012, 109:17531-17536.

9. Barkauskas CE, Cronce MJ, Rackley CR, Bowie EJ, Keene DR, Stripp BR, Randell SH, Noble PW, Hogan BL: Type 2 alveolar cells are stem cells in adult lung. J Clin Invest 2013, 123:3025-3036.

10. Desai TJ, Brownfield DG, Krasnow MA: Alveolar progenitor and stem cells in lung development, renewal and cancer. Nature 2014, 507:190-194.

11. Hegab AE, Ha VL, Gilbert JL, Zhang KX, Malkoski SP, Chon AT, Darmawan DO, Bisht B, Ooi AT, Pellegrini M, Nickerson DW, Gomperts BN: Novel stem/progenitor cell population from murine tracheal submucosal gland ducts with multipotent regenerative potential. Stem Cells 2011, 29:1283-1293.
12. Hegab AE, Nickerson DW, Ha VL, Darmawan DO, Gomperts BN: Repair and regeneration of tracheal surface epithelium and submucosal glands in a mouse model of hypoxic-ischemic injury. Respirology 2012, 17:1101-1113.

13. Tata PR, Mou H, Pardo-Saganta A, Zhao R, Prabhu M, Law BM, Vinarsky V, Cho JL, Breton S, Sahay A, Medoff BD, Rajagopal J: Dedifferentiation of committed epithelial cells into stem cells in vivo. Nature 2013, 503:218-223.

14. Daniely Y, Liao G, Dixon D, Linnoila RI, Lori A, Randell SH, Oren M, Jetten AM: Critical role of p63 in the development of a normal esophageal and tracheobronchial epithelium. Am J Physiol Cell Physiol 2004, 287:C171-C181.

15. Koster MI, Kim S, Mills AA, DeMayo FJ, Roop DR: p63 is the molecular switch for initiation of an epithelial stratification program. Genes Dev 2004, 18:126-131.

16. Reynolds SD, Giangreco A, Power JH, Stripp BR: Neuroepithelial bodies of pulmonary airways serve as a reservoir of progenitor cells capable of epithelial regeneration. Am J Pathol 2000, 156:269-278.

17. Giangreco A, Arwert EN, Rosewell IR, Snyder J, Watt FM, Stripp BR: Stem cells are dispensable for lung homeostasis but restore airways after injury. Proc Natl Acad Sci U S A 2009, 106:9286-9291.

18. Giangreco A, Reynolds SD, Stripp BR: Terminal bronchioles harbor a unique airway stem cell population that localizes to the bronchoalveolar duct junction. Am J Pathol 2002, 161:173-182

19. Kim CF, Jackson EL, Woolfenden AE, Lawrence S, Babar I, Vogel S, Crowley D, Bronson RT, Jacks T: Identification of bronchioalveolar stem cells in normal lung and lung cancer. Cell 2005, 121:823-835.

20. Kumar PA, Hu Y, Yamamoto $Y$, Hoe NB, Wei TS, Mu D, Sun Y, Joo LS, Dagher R, Zielonka EM, Wangde Y, Lim B, Chow VT, Crum CP, Xian W, McKeon F: Distal airway stem cells yield alveoli in vitro and during lung regeneration following H1N1 influenza infection. Cell 2011, 147:525-538.

21. Chen H, Matsumoto K, Brockway BL, Rackley CR, Liang J, Lee JH, Jiang D, Noble PW, Randell SH, Kim CF, Stripp BR: Airway epithelial progenitors are region specific and show differential responses to bleomycin-induced lung injury. Stem Cells 2012, 30:1948-1960.

22. Lee JH, Bhang DH, Beede A, Huang TL, Stripp BR, Bloch KD, Wagers AJ, Tseng YH, Ryeom S, Kim CF: Lung stem cell differentiation in mice directed by endothelial cells via a BMP4-NFATc1-thrombospondin-1 axis. Cell 2014, 156:440-455

23. Rock JR, Barkauskas CE, Cronce MJ, Xue Y, Harris JR, Liang J, Noble PW, Hogan BL: Multiple stromal populations contribute to pulmonary fibrosis without evidence for epithelial to mesenchymal transition. Proc Natl Acad Sci U S A 2011, 108:E1475-1483.

24. Zheng D, Limmon GV, Yin L, Leung NH, Yu H, Chow VT, Chen J: Regeneration of alveolar type I and II cells from Scgb1a1-expressing cells following severe pulmonary damage induced by bleomycin and influenza. PLoS One 2012, 7:e48451.

25. Zheng D, Yin L, Chen J: Evidence for Scgb1a1 cells in the generation of p63 cells in the damaged lung parenchyma. Am J Respir Cell Mol Biol 2013, 50:595-604.

26. Chilosi M, Poletti V, Murer B, Lestani M, Cancellieri A, Montagna L, Piccoli P, Cangi G, Semenzato G, Doglioni C: Abnormal re-epithelialization and lung remodeling in idiopathic pulmonary fibrosis: the role of deltaN-p63. Lab Invest 2002, 82:1335-1345.

27. Chapman HA, Li X, Alexander JP, Brumwell A, Lorizio W, Tan K, Sonnenberg A, Wei $Y, V u$ TH: Integrin alpha6beta4 identifies an adult distal lung epithelial population with regenerative potential in mice. J Clin Invest 2011, 121:2855-2862.

28. McQualter JL, Yuen K, Williams B, Bertoncello I: Evidence of an epithelial stem/progenitor cell hierarchy in the adult mouse lung. Proc Natl Acad Sci U S A 2010, 107:1414-1419.

29. Watt FM, Driskell RR: The therapeutic potential of stem cells. Philos Trans $R$ Soc Lond B Biol Sci 2010, 365:155-163.

30. Hsu YC, Fuchs E: A family business: stem cell progeny join the niche to regulate homeostasis. Nat Rev Mol Cell Biol 2012, 13:103-114.

31. Hsu YC, Pasolli HA, Fuchs E: Dynamics between stem cells, niche, and progeny in the hair follicle. Cell 2011, 144:92-105.

32. Ornitz DM, Yin Y: Signaling networks regulating development of the lower respiratory tract. Cold Spring Harb Perspect Biol 2012, 4:a008318.

33. Rawlins EL, Clark CP, Xue Y, Hogan BL: The Id2+ distal tip lung epithelium contains individual multipotent embryonic progenitor cells. Development 2009, 136:3741-3745. 
34. Chen F, Cao Y, Qian J, Shao F, Niederreither K, Cardoso WV: A retinoic acid-dependent network in the foregut controls formation of the mouse lung primordium. J Clin Invest 2010, 120:2040-2048.

35. De Langhe SP, Carraro G, Tefft D, Li C, Xu X, Chai Y, Minoo P, Hajihosseini MK, Drouin J, Kaartinen V, Bellusci S: Formation and differentiation of multiple mesenchymal lineages during lung development is regulated by beta-catenin signaling. PLOS One 2008, 3:e1516.

36. Goss AM, Tian Y, Cheng L, Yang J, Zhou D, Cohen ED, Morrisey EE: Wnt2 signaling is necessary and sufficient to activate the airway smooth muscle program in the lung by regulating myocardin/Mrtf-B and Fgf10 expression. Dev Biol 2011, 356:541-552.

37. Nyeng P, Norgaard GA, Kobberup S, Jensen J: FGF10 maintains distal lung bud epithelium and excessive signaling leads to progenitor state arrest, distalization, and goblet cell metaplasia. BMC Dev Biol 2008, 8:2.

38. Ramasamy SK, Mailleux AA, Gupte W, Mata F, Sala FG, Veltmaat JM, Del Moral PM, De Langhe S, Parsa S, Kelly LK, Kelly R, Shia W, Keshet E, Minoo P, Warburton D, Bellusci S: Fgf10 dosage is critical for the amplification of epithelial cell progenitors and for the formation of multiple mesenchymal lineages during lung development. Dev Biol 2007, 307:237-247.

39. Izvolsky Kl, Shoykhet D, Yang Y, Yu Q, Nugent MA, Cardoso WV: Heparan sulfate-FGF10 interactions during lung morphogenesis. Dev Biol 2003, 258:185-200.

40. Izvolsky Kl, Zhong L, Wei L, Yu Q, Nugent MA, Cardoso WV: Heparan sulfates expressed in the distal lung are required for Fgf10 binding to the epithelium and for airway branching. Am J Physiol Lung Cell Mol Physiol 2003, 285:L838-L846.

41. Sedita J, Izvolsky K, Cardoso WV: Differential expression of heparan sulfate 6-O-sulfotransferase isoforms in the mouse embryo suggests distinctive roles during organogenesis. Dev Dyn 2004, 231:782-794.

42. Bellusci S, Grindley J, Emoto H, Itoh N, Hogan BL: Fibroblast growth factor 10 (FGF10) and branching morphogenesis in the embryonic mouse lung. Development 1997, 124:4867.

43. Volckaert T, Campbell A, Dill E, Li C, Minoo P, De Langhe S: Localized Fgf10 expression is not required for lung branching morphogenesis but prevents differentiation of epithelial progenitors. Development 2013, 140:3731-3742.

44. Shimokawa K, Kimura-Yoshida C, Nagai N, Mukai K, Matsubara K, Watanabe H, Matsuda Y, Mochida K, Matsuo I: Cell surface heparan sulfate chains regulate local reception of FGF signaling in the mouse embryo. Dev Cell 2011, 21:257-272

45. McKeehan WL, Wang F, Kan M: The heparan sulfate-fibroblast growth factor family: diversity of structure and function. Prog Nucleic Acid Res Mol Biol 1998, 59:135-176.

46. Rockich BE, Hrycaj SM, Shih HP, Nagy MS, Ferguson MA, Kopp JL, Sander M, Wellik DM, Spence JR: Sox9 plays multiple roles in the lung epithelium during branching morphogenesis. Proc Natl Acad Sci U S A 2013, 110:E4456-E4464.

47. Chang DR, Martinez Alanis D, Miller RK, Ji H, Akiyama H, McCrea PD, Chen J: Lung epithelial branching program antagonizes alveolar differentiation. Proc Natl Acad Sci U S A 2013, 110:18042-18051.

48. El Agha E, Al Alam D, Carraro G, MacKenzie B, Goth K, De Langhe SP, Voswinckel R, Hajihosseini MK, Rehan VK, Bellusci S: Characterization of a novel fibroblast growth factor 10 (Fgf10) knock-in mouse line to target mesenchymal progenitors during embryonic development. PLoS One 2012, 7:e38452.

49. Mailleux AA, Kelly R, Veltmaat JM, De Langhe SP, Zaffran S, Thiery JP, Bellusci S: Fgf10 expression identifies parabronchial smooth muscle cell progenitors and is required for their entry into the smooth muscle cell lineage. Development 2005, 132:2157-2166.

50. El Agha E, Herhold S, Al Alam D, Quantius J, MacKenzie B, Carraro G, Moiseenko A, Chao CM, Minoo P, Seeger W, Bellusci S: Fgf10-positive cells represent a progenitor cell population during lung development and postnatally. Development 2014, 141:296-306.

51. Tiozzo C, De Langhe S, Carraro G, Alam DA, Nagy A, Wigfall C, Hajihosseini MK, Warburton D, Minoo P, Bellusci S: Fibroblast growth factor 10 plays a causative role in the tracheal cartilage defects in a mouse model of Apert syndrome. Pediatr Res 2009, 66:386-390

52. Sala FG, Del Moral PM, Tiozzo C, Alam DA, Warburton D, Grikscheit T, Veltmaat JM, Bellusci S: FGF10 controls the patterning of the tracheal cartilage rings via Shh. Development 2011, 138:273-282.
53. De Langhe SP, Carraro G, Warburton D, Hajihosseini MK, Bellusci S: Levels of mesenchymal FGFR2 signaling modulate smooth muscle progenitor cell commitment in the lung. Dev Biol 2006, 299:52-62.

54. Volckaert T, Dill E, Campbell A, Tiozzo C, Majka S, Bellusci S, De Langhe SP: Parabronchial smooth muscle constitutes an airway epithelial stem cell niche in the mouse lung after injury. J Clin Invest 2011, 121:4409-4419.

55. Volckaert T, Campbell A, De Langhe S: c-Myc regulates proliferation and Fgf10 expression in airway smooth muscle after airway epithelial injury in mouse. PLoS One 2013, 8:e71426.

56. Gupte W, Ramasamy SK, Reddy R, Lee J, Weinreb PH, Violette SM, Guenther A, Warburton D, Driscoll B, Minoo P, Bellusci S: Overexpression of fibroblast growth factor-10 during both inflammatory and fibrotic phases attenuates bleomycin-induced pulmonary fibrosis in mice. Am J Respir Crit Care Med 2009, 180:424-436.

57. Borthwick DW, Shahbazian M, Krantz QT, Dorin JR, Randell SH: Evidence for stem-cell niches in the tracheal epithelium. Am J Respir Cell Mol Biol 2001, 24:662-670.

58. Xie W, Fisher JT, Lynch TJ, Luo M, Evans TI, Neff TL, Zhou W, Zhang Y, Ou Y, Bunnett NW, Russo AF, Goodheart MJ, Parekh KR, Liu X, Engelhardt JF: CGRP induction in cystic fibrosis airways alters the submucosal gland progenitor cell niche in mice. J Clin Invest 2011, 121:3144-3158.

59. Rawlins EL, Hogan BL: Intercellular growth factor signaling and the development of mouse tracheal submucosal glands. Dev Dyn 2005, 233:1378-1385

60. Morimoto M, Nishinakamura R, Saga Y, Kopan R: Different assemblies of Notch receptors coordinate the distribution of the major bronchial Clara, ciliated and neuroendocrine cells. Development 2012, 139:4365-4373.

61. Guha A, Vasconcelos M, Cai Y, Yoneda M, Hinds A, Qian J, Li G, Dickel L, Johnson JE, Kimura S, Guo J, McMahon J, McMahon AP, Cardoso W: Neuroepithelial body microenvironment is a niche for a distinct subset of Clara-like precursors in the developing airways. Proc Natl Acad Sci US A 2012, 109:12592-12597.

62. Reynolds SD, Hong KU, Giangreco A, Mango GW, Guron C, Morimoto Y, Stripp BR: Conditional clara cell ablation reveals a self-renewing progenitor function of pulmonary neuroendocrine cells. Am J Physiol Lung Cell Mol Physiol 2000, 278:L1256-L1263

63. Beers MF, Morrisey EE: The three R's of lung health and disease: repair remodeling, and regeneration. J Clin Invest 2011, 121:2065-2073.

64. King TE Jr, Pardo A, Selman M: Idiopathic pulmonary fibrosis. Lancet 2011, 378:1949-1961

65. Selman M, Pardo A, Kaminski N: Idiopathic pulmonary fibrosis: aberrant recapitulation of developmental programs? PLOS Med 2008, 5:e62.

66. Rehan VK, Sugano S, Wang Y, Santos J, Romero S, Dasgupta C, Keane MP Stahlman MT, Torday JS: Evidence for the presence of lipofibroblasts in human lung. Exp Lung Res 2006, 32:379-393.

67. Kaplan NB, Grant MM, Brody JS: The lipid interstitial cell of the pulmonary alveolus. Age and species differences. Am Rev Respir Dis 1985, 132:1307-1312

68. Tordet C, Marin L, Dameron F: Pulmonary di-and-triacylglycerols during the perinatal development of the rat. Experientia 1981, 37:333-334.

69. Simon DM, Mariani TJ: Role of PPARs and retinoid X receptors in the regulation of lung maturation and development. PPAR Res 2007 2007:91240

70. O'Hare KH, Sheridan MN: Electron microscopic observations on the morphogenesis of the albino rat lung, with special reference to pulmonary epithelial cells. Am J Anat 1970, 127:181-205.

71. McGowan SE, Torday JS: The pulmonary lipofibroblast (lipid interstitial cell) and its contributions to alveolar development. Annu Rev Physiol 1997, 59:43-62

72. Clark JC, Tichelaar JW, Wert SE, Itoh N, Perl AK, Stahlman MT, Whitsett JA: FGF-10 disrupts lung morphogenesis and causes pulmonary adenomas in vivo. Am J Physiol Lung Cell Mol Physiol 2001, 280:L705-L715.

73. Hyatt BA, Shangguan X, Shannon JM: FGF-10 induces SP-C and Bmp4 and regulates proximal-distal patterning in embryonic tracheal epithelium. Am J Physiol Lung Cell Mol Physiol 2004, 287:L1116-L1126.

74. McQualter JL, McCarty RC, Van der Velden J, O'Donoghue RJ, Asselin-Labat ML, Bozinovski S, Bertoncello I: TGF-beta signaling in stromal cells acts upstream of FGF-10 to regulate epithelial stem cell growth in the adult lung. Stem Cell Res 2013, 11:1222-1233. 
75. Chen F, Desai TJ, Qian J, Niederreither K, Lu J, Cardoso WV: Inhibition of Tgf beta signaling by endogenous retinoic acid is essential for primary lung bud induction. Development 2007, 134:2969-2979.

76. Shu W, Guttentag S, Wang Z, Andl T, Ballard P, Lu MM, Piccolo S, Birchmeier W, Whitsett JA, Millar SE, Morrisey EE: Wnt/beta-catenin signaling acts upstream of N-myc, BMP4, and FGF signaling to regulate proximal-distal patterning in the lung. Dev Biol 2005, 283:226-239.

77. Sekine K, Ohuchi H, Fujiwara M, Yamasaki M, Yoshizawa T, Sato T, Yagishita N, Matsui D, Koga Y, Itoh N, Kato S: Fgf10 is essential for limb and lung formation. Nat Genet 1999, 21:138-141.

78. Weaver M, Dunn NR, Hogan BL: Bmp4 and Fgf10 play opposing roles during lung bud morphogenesis. Development 2000, 127:2695-2704.

79. Ruiz EJ, Oeztuerk-Winder F, Ventura JJ: A paracrine network regulates the cross-talk between human lung stem cells and the stroma. Nat Commun 2014, 5:3175.

80. Engler AJ, Sen S, Sweeney HL, Discher DE: Matrix elasticity directs stem cell lineage specification. Cell 2006, 126:677-689.

81. Gilbert PM, Havenstrite KL, Magnusson KE, Sacco A, Leonardi NA, Kraft P, Nguyen NK, Thrun S, Lutolf MP, Blau HM: Substrate elasticity regulates skeletal muscle stem cell self-renewal in culture. Science 2010 329:1078-1081.

82. Yamazaki S, Ema H, Karlsson G, Yamaguchi T, Miyoshi H, Shioda S, Taketo MM, Karlsson S, Iwama A, Nakauchi H: Nonmyelinating Schwann cells maintain hematopoietic stem cell hibernation in the bone marrow niche. Cell 2011, 147:1146-1158.

83. Ellis SJ, Tanentzapf G: Integrin-mediated adhesion and stem-cell-niche interactions. Cell Tissue Res 2010, 339:121-130.

84. Grose R, Hutter C, Bloch W, Thorey I, Watt FM, Fassler R, Brakebusch C, Werner S: A crucial role of beta 1 integrins for keratinocyte migration in vitro and during cutaneous wound repair. Development 2002 129:2303-2315.

85. Watt FM: Role of integrins in regulating epidermal adhesion, growth and differentiation. EMBO J 2002, 21:3919-3926

86. Laurent GJ: Dynamic state of collagen: pathways of collagen degradation in vivo and their possible role in regulation of collagen mass. Am J Physiol 1987, 252:C1-C9.

87. Rock J, Konigshoff M: Endogenous lung regeneration: potential and limitations. Am J Respir Crit Care Med 2012, 186:1213-1219.

88. Roskelley CD, Srebrow A, Bissell MJ: A hierarchy of ECM-mediated signalling regulates tissue-specific gene expression. Curr Opin Cell Biol 1995, 7:736-747

89. Schwartz MA, Baron V: Interactions between mitogenic stimuli, or, a thousand and one connections. Curr Opin Cell Biol 1999, 11:197-202.

90. Giancotti FG, Ruoslahti E: Integrin signaling. Science 1999, 285:1028-1032.

91. Radisky D, Muschler J, Bissell MJ: Order and disorder: the role of extracellular matrix in epithelial cancer. Cancer Invest 2002, 20:139-153.

92. Song JJ, Ott HC: Organ engineering based on decellularized matrix scaffolds. Trends Mol Med 2011, 17:424-432.

93. Watt FM, Fujiwara $\mathrm{H}$ : Cell-extracellular matrix interactions in normal and diseased skin. Cold Spring Harb Perspect Biol 2011, 3:a005124.

94. Orford KW, Scadden DT: Deconstructing stem cell self-renewal: genetic insights into cell-cycle regulation. Nat Rev Genet 2008, 9:115-128.

95. Yu FX, Guan KL: The Hippo pathway: regulators and regulations. Genes Dev 2013, 27:355-371.

96. Zhao B, Tumaneng K, Guan KL: The Hippo pathway in organ size control, tissue regeneration and stem cell self-renewal. Nat Cell Biol 2011, 13:877-883.

97. Yates LL, Schnatwinkel C, Hazelwood L, Chessum L, Paudyal A, Hilton H, Romero MR, Wilde J, Bogani D, Sanderson J, Formstone C, Murdoch JN, Niswander LA, Greenfield A, Dean CH: Scribble is required for normal epithelial cell-cell contacts and lumen morphogenesis in the mammalian lung. Dev Biol 2012, 373:267-280

98. Barry ER, Camargo FD: The Hippo superhighway: signaling crossroads converging on the Hippo/Yap pathway in stem cells and development. Curr Opin Cell Biol 2013, 25:247-253.

99. Bernascone I, Martin-Belmonte F: Crossroads of Wnt and Hippo in epithelial tissues. Trends Cell Biol 2013, 23:380-389.

100. Dupont S, Morsut L, Aragona M, Enzo E, Giulitti S, Cordenonsi M, Zanconato F, Le Digabel J, Forcato M, Bicciato S, Elvassore N, Piccolo S: Role of YAP/TAZ in mechanotransduction. Nature 2011, 474:179-183.
101. Halder G, Johnson RL: Hippo signaling: growth control and beyond. Development 2011, 138:9-22.

102. Harvey KF, Zhang $X$, Thomas DM: The Hippo pathway and human cancer. Nat Rev Cancer 2013, 13:246-257.

103. Hong W, Guan KL: The YAP and TAZ transcription co-activators: key downstream effectors of the mammalian Hippo pathway. Semin Cell Dev Biol 2012, 23:785-793.

104. Johnson R, Halder G: The two faces of Hippo: targeting the Hippo pathway for regenerative medicine and cancer treatment. Nat Rev Drug Discov 2013, 13:63-79.

105. Lin Jl, Poon CL, Harvey KF: The Hippo size control pathway-ever expanding. Sci Signal 2013, 6:pe4.

106. Zhao B, Wei X, Li W, Udan RS, Yang Q, Kim J, Xie J, Ikenoue T, Yu J, Li L, Zheng P, Ye K, Chinnaiyan A, Halder G, Lai ZC, Guan KL: Inactivation of YAP oncoprotein by the Hippo pathway is involved in cell contact inhibition and tissue growth control. Genes Dev 2007, 21:2747-2761.

107. Overholtzer M, Zhang J, Smolen GA, Muir B, Li W, Sgroi DC, Deng CX, Brugge JS, Haber DA: Transforming properties of YAP, a candidate oncogene on the chromosome 11q22 amplicon. Proc Natl Acad Sci U S A 2006, 103:12405-12410.

108. Roche WR, Beasley R, Williams JH, Holgate ST: Subepithelial fibrosis in the bronchi of asthmatics. Lancet 1989, 1:520-524.

109. Brewster CE, Howarth PH, Djukanovic R, Wilson J, Holgate ST, Roche WR: Myofibroblasts and subepithelial fibrosis in bronchial asthma. Am J Respir Cell Mol Biol 1990, 3:507-511.

110. Descalzi D, Folli C, Scordamaglia F, Riccio AM, Gamalero C, Canonica GW: Importance of fibroblasts-myofibroblasts in asthma-induced airway remodeling. Recent Pat Inflamm Allergy Drug Discov 2007, 1:237-241.

111. Hackett TL, Shaheen F, Johnson A, Wadsworth S, Pechkovsky DV, Jacoby DB, Kicic A, Stick SM, Knight DA: Characterization of side population cells from human airway epithelium. Stem Cells 2008, 26:2576-2585.

112. Hackett TL, Warner SM, Stefanowicz D, Shaheen F, Pechkovsky DV Murray LA, Argentieri R, Kicic A, Stick SM, Bai TR, Knight DA: Induction of epithelial-mesenchymal transition in primary airway epithelial cells from patients with asthma by transforming growth factor-beta1. Am J Respir Crit Care Med 2009, 180:122-133.

113. Ordonez $\mathrm{CL}$, Khashayar R, Wong HH, Ferrando R, Wu R, Hyde DM, Hotchkiss JA, Zhang Y, Novikov A, Dolganov G, Fahy JV: Mild and moderate asthma is associated with airway goblet cell hyperplasia and abnormalities in mucin gene expression. Am J Respir Crit Care Med 2001, 163:517-523.

114. Jeffery P, Zhu J: Mucin-producing elements and inflammatory cells. Novartis Found Symp 2002, 248:51-68. Discussion 68-75, 277-282.

115. Shimura S, Andoh Y, Haraguchi M, Shirato K: Continuity of airway goblet cells and intraluminal mucus in the airways of patients with bronchial asthma. Eur Respir J 1996, 9:1395-1401.

116. Pardo-Saganta A, Law BM, Gonzalez-Celeiro M, Vinarsky V, Rajagopal J: Ciliated cells of pseudostratified airway epithelium do not become mucous cells after OVA challenge. Am J Respir Cell Mol Biol 2013, 48:364-373.

117. Chen G, Korfhagen TR, Xu Y, Kitzmiller J, Wert SE, Maeda Y, Gregorieff A, Clevers $H$, Whitsett JA: SPDEF is required for mouse pulmonary goblet cell differentiation and regulates a network of genes associated with mucus production. J Clin Invest 2009, 119:2914-2924.

118. Park KS, Korfhagen TR, Bruno MD, Kitzmiller JA, Wan H, Wert SE, Khurana Hershey GK, Chen G, Whitsett JA: SPDEF regulates goblet cell hyperplasia in the airway epithelium. J Clin Invest 2007, 117:978-988.

119. Guseh JS, Bores SA, Stanger BZ, Zhou Q, Anderson WJ, Melton DA, Rajagopal J: Notch signaling promotes airway mucous metaplasia and inhibits alveolar development. Development 2009, 136:1751-1759.

120. Tompkins DH, Besnard V, Lange AW, Wert SE, Keiser AR, Smith AN, Lang R, Whitsett JA: Sox2 is required for maintenance and differentiation of bronchiolar Clara, ciliated, and goblet cells. PLoS One 2009, 4:e8248.

121. Roy MG, Rahmani M, Hernandez JR, Alexander SN, Ehre C, Ho SB, Evans CM: Mucin production during pre- and post-natal mouse lung development. Am J Respir Cell Mol Biol 2011, 44(6):755-760.

122. Evans CM, Williams OW, Tuvim MJ, Nigam R, Mixides GP, Blackburn MR, DeMayo FJ, Burns AR, Smith C, Reynolds SD, Stripp BR, Dickey BF: Mucin is produced by clara cells in the proximal airways of antigen-challenged mice. Am J Respir Cell Mol Biol 2004, 31:382-394.

123. Lambrecht BN, Hammad H: The airway epithelium in asthma. Nat Med 2012, 18:684-692. 
124. Baraldo S, Turato G, Bazzan E, Ballarin A, Damin M, Balestro E, Lokar Oliani K, Calabrese F, Maestrelli P, Snijders D, Barbato A, Saetta M: Noneosinophilic asthma in children: relation with airway remodelling. Eur Respir J 2011 38:575-583.

125. Barbato A, Turato G, Baraldo S, Bazzan E, Calabrese F, Panizzolo C, Zanin ME, Zuin R, Maestrelli P, Fabbri LM, Saetta M: Epithelial damage and angiogenesis in the airways of children with asthma. Am J Respir Crit Care Med 2006, 174:975-981.

126. Malmstrom K, Pelkonen AS, Malmberg LP, Sarna S, Lindahl H, Kajosaari M, Turpeinen M, Saglani S, Bush A, Haahtela T, Jeffery PK, Mäkelä MJ: Lung function, airway remodelling and inflammation in symptomatic infants: outcome at 3 years. Thorax 2011, 66:157-162.

127. Crosby LM, Waters CM: Epithelial repair mechanisms in the lung. Am J Physiol Lung Cell Mol Physiol 2010, 298:L715-L731.

128. Holgate ST, Roberts G, Arshad HS, Howarth PH, Davies DE: The role of the airway epithelium and its interaction with environmental factors in asthma pathogenesis. Proc Am Thorac Soc 2009, 6:655-659.

129. Knight DA, Holgate ST: The airway epithelium: structural and functional properties in health and disease. Respirology 2003, 8:432-446.

130. Royce SG, Li X, Tortorella S, Goodings L, Chow BS, Giraud AS, Tang ML, Samuel CS: Mechanistic insights into the contribution of epithelial damage to airway remodeling: novel therapeutic targets for asthma. Am J Respir Cell Mol Biol 2013, 50:180-192.

131. Palmer CN, Invine AD, Terron-Kwiatkowski A, Zhao Y, Liao H, Lee SP, Goudie DR, Sandilands A, Campbell LE, Smith FJ, O'Regan GM, Watson RM, Cecil JE, Bale SJ, Compton JG, DiGiovanna JJ, Fleckman P, Lewis-Jones S, Arseculeratne G, Sergeant A, Munro CS, El Houate B, McElreavey K, Halkjaer LB, Bisgaard H, Mukhopadhyay S, McLean WH: Common loss-of-function variants of the epidermal barrier protein filaggrin are a major predisposing factor for atopic dermatitis. Nat Genet 2006, 38:441-446.

132. Nawijn MC, Hackett TL, Postma DS, van Oosterhout AJ, Heijink IH: E-cadherin: gatekeeper of airway mucosa and allergic sensitization. Trends Immunol 2011, 32:248-255.

133. Kim JY, Sajjan US, Krasan GP, LiPuma JJ: Disruption of tight junctions during traversal of the respiratory epithelium by Burkholderia cenocepacia. Infect Immun 2005, 73:7107-7112.

134. Wan H, Winton HL, Soeller C, Taylor GW, Gruenert DC, Thompson PJ, Cannell MB, Stewart GA, Garrod DR, Robinson C: The transmembrane protein occludin of epithelial tight junctions is a functional target for serine peptidases from faecal pellets of Dermatophagoides pteronyssinus. Clin Exp Allergy 2001, 31:279-294.

135. Wan H, Winton HL, Soeller C, Tovey ER, Gruenert DC, Thompson PJ, Stewart GA, Taylor GW, Garrod DR, Cannell MB, Robinson C: Der p 1 facilitates transepithelial allergen delivery by disruption of tight junctions. J Clin Invest 1999, 104:123-133.

136. de Blic J, Scheinmann P: The use of imaging techniques for assessing severe childhood asthma. J Allergy Clin Immunol 2007, 119:808-810.

137. Vermeer PD, Einwalter LA, Moninger TO, Rokhlina T, Kern JA, Zabner J, Welsh MJ: Segregation of receptor and ligand regulates activation of epithelial growth factor receptor. Nature 2003, 422:322-326.

138. Holgate ST, Davies DE, Powell RM, Howarth PH, Haitchi HM, Holloway JW: Local genetic and environmental factors in asthma disease pathogenesis: chronicity and persistence mechanisms. Eur Respir J 2007, 29:793-803.

139. Cohen ED, Ihida-Stansbury K, Lu MM, Panettieri RA, Jones PL, Morrisey EE: Wnt signaling regulates smooth muscle precursor development in the mouse lung via a tenascin C/PDGFR pathway. J Clin Invest 2009, 119:2538-2549.

140. Tsao PN, Vasconcelos M, Izvolsky KI, Qian J, Lu J, Cardoso W: Notch signaling controls the balance of ciliated and secretory cell fates in developing airways. Development 2009, 136:2297-2307.

141. Rowe RG, Lin Y, Shimizu-Hirota R, Hanada S, Neilson EG, Greenson JK, Weiss SJ: Hepatocyte-derived Snail1 propagates liver fibrosis progression. Mol Cell Biol 2011, 31:2392-2403.

142. Armanios MY, Chen JJ, Cogan JD, Alder JK, Ingersoll RG, Markin C, Lawson WE, Xie M, Vulto I, Phillips JA 3rd, Lansdorp PM, Greider CW, Loyd JE: Telomerase mutations in families with idiopathic pulmonary fibrosis. N Engl J Med 2007, 356:1317-1326.

143. Liu T, Chung MJ, Ullenbruch M, Yu H, Jin H, Hu B, Choi YY, Ishikawa F, Phan SH: Telomerase activity is required for bleomycin-induced pulmonary fibrosis in mice. J Clin Invest 2007, 117:3800-3809.
144. Tsakiri KD, Cronkhite JT, Kuan PJ, Xing C, Raghu G, Weissler JC, Rosenblatt RL, Shay JW, Garcia CK: Adult-onset pulmonary fibrosis caused by mutations in telomerase. Proc Natl Acad Sci U S A 2007, 104:7552-7557.

145. Waisberg DR, Barbas-Filho JV, Parra ER, Fernezlian S, de Carvalho CR, Kairalla RA, Capelozzi VL: Abnormal expression of telomerase/apoptosis limits type II alveolar epithelial cell replication in the early remodeling of usual interstitial pneumonia/idiopathic pulmonary fibrosis. Hum Pathol 2010, 41:385-391.

146. Alder JK, Cogan JD, Brown AF, Anderson CJ, Lawson WE, Lansdorp PM, Phillips JA 3rd, Loyd JE, Chen JJ, Armanios M: Ancestral mutation in telomerase causes defects in repeat addition processivity and manifests as familial pulmonary fibrosis. PLoS Genet 2011, 7:e1001352.

147. Armanios M: Telomerase mutations and the pulmonary fibrosis-bone marrow failure syndrome complex. N Engl J Med 2012, 367:384. Author reply 384 .

148. Gansner JM, Rosas IO, Ebert BL: Pulmonary fibrosis, bone marrow failure, and telomerase mutation. N Engl J Med 2012, 366:1551-1553.

149. Liu T, Ullenbruch M, Young Choi Y, Yu H, Ding L, Xaubet A, Pereda J, Feghali-Bostwick CA, Bitterman PB, Henke CA, Pardo A, Selman M, Phan SH: Telomerase and telomere length in pulmonary fibrosis. Am J Respir Cell Mol Biol 2013, 49:260-268.

150. Thannickal VJ, Toews GB, White ES, Lynch JP 3rd, Martinez FJ: Mechanisms of pulmonary fibrosis. Annu Rev Med 2004, 55:395-417.

151. Wang XM, Zhang Y, Kim HP, Zhou Z, Feghali-Bostwick CA, Liu F, Ifedigbo $E_{\text {, }}$ Xu X, Oury TD, Kaminski N, Choi AM: Caveolin-1: a critical regulator of lung fibrosis in idiopathic pulmonary fibrosis. J Exp Med 2006, 203:2895-2906.

152. Shi F, Sottile J: Caveolin-1-dependent beta1 integrin endocytosis is a critical regulator of fibronectin turnover. J Cell Sci 2008, 121:2360-2371.

153. Razani $B$, Wang XB, Engelman JA, Battista M, Lagaud G, Zhang XL, Kneitz B, Hou H Jr, Christ GJ, Edelmann W, Lisanti MP: Caveolin-2-deficient mice show evidence of severe pulmonary dysfunction without disruption of caveolae. Mol Cell Biol 2002, 22:2329-2344.

154. Klar J, Blomstrand P, Brunmark C, Badhai J, Hakansson HF, Brange CS, Bergendal B, Dahl N: Fibroblast growth factor 10 haploinsufficiency causes chronic obstructive pulmonary disease. J Med Genet 2011, 48:705-709.

155. Yui S, Nakamura T, Sato T, Nemoto $Y$, Mizutani T, Zheng X, Ichinose $S$, Nagaishi T, Okamoto R, Tsuchiya K, Clevers H, Watanabe M: Functional engraftment of colon epithelium expanded in vitro from a single adult Lgr5(+) stem cell. Nat Med 2012, 18:618-623.

doi:10.1186/1755-1536-7-8

Cite this article as: Volckaert and De Langhe: Lung epithelial stem cells and their niches: Fgf10 takes center stage. Fibrogenesis \& Tissue Repair 2014 7:8.

\section{Submit your next manuscript to BioMed Central and take full advantage of:}

- Convenient online submission

- Thorough peer review

- No space constraints or color figure charges

- Immediate publication on acceptance

- Inclusion in PubMed, CAS, Scopus and Google Scholar

- Research which is freely available for redistribution 